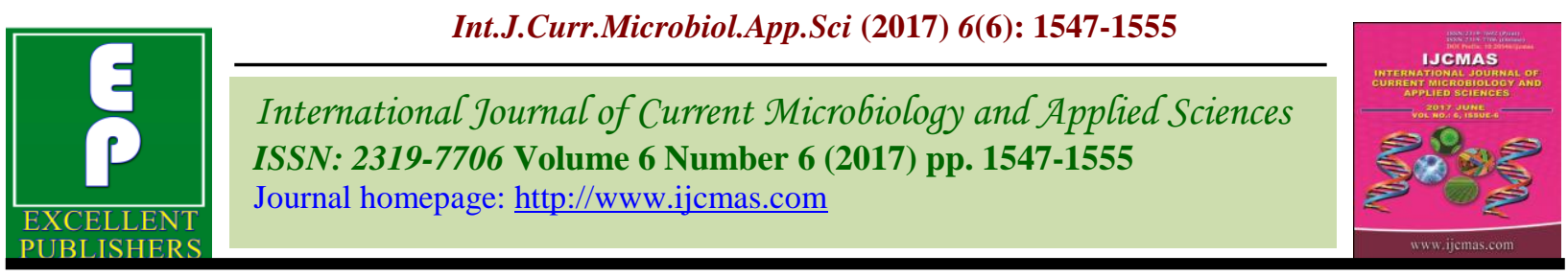

Original Research Article

https://doi.org/10.20546/ijcmas.2017.606.182

\title{
Studies on Boron Fractions with Different Physico-Chemical Properties of Cultivated Soils of Himachal Pradesh, India
}

\author{
Kusum Kumari, Gazala Nazir*, Ajeet Singh and Pardeep Kumar \\ Department of Soil Science, CSK HPKV, Palampur, India \\ *Corresponding author
}

A B S T R A C T

Sorption of boron (B) an important phenomenon in soils regulates its supply for plant growth. However, there are many soil characteristics which influence B adsorptiondesorption capacity. Therefore, 80 soil samples $(0-0.15 \mathrm{~m}$ depth) varying in mechanical soil

Keywords separates (sand, silt and clay), soil $\mathrm{pH}$, organic carbon (OC), cation exchange capacity (CEC) and clay content were collected from different districts of Himachal Pradesh and

Boron fraction,

Physical and

Chemical properties.

Article Info

Accepted:

21 May 2017

Available Online:

10 June 2017 their B fractions and soil properties were determined. Soil $\mathrm{pH}(1: 2.5), \mathrm{OC}\left(\mathrm{g} \mathrm{kg}^{-1}\right), \mathrm{CEC}$ $\left(\mathrm{cmol}\left(\mathrm{p}^{+}\right) \mathrm{kg}^{-1}\right)$, textural class of the soils in the range of 5.48-7.45, 5.3-23.5, 4.6-15.4 and sandy loam to sandy clay, respectively. Different B fractions viz. readily soluble, specifically adsorbed, oxide bound, organically bound, residual and total were characterized according to fractionation scheme and their contents varied in the range of $0.12-0.55,0.21-0.62,0.26-1.67,0.32-2.34,19.5-25.7$ and $20.6-29.5 \mathrm{mg} \mathrm{kg}^{-1}$, respectively. Residual B was the most dominant pool of soil B contributing about 90.3 per cent of total. The relative contribution of other fractions was in the order, organically bound $\mathrm{B}>$ oxide bound $\mathrm{B}>$ specifically adsorbed $\mathrm{B}>$ readily soluble $\mathrm{B}$. Soil $\mathrm{pH}$, OC and CEC were positively correlated with all boron fractions whereas oxide bound B was negatively correlated.The results emanating from the study revealed that with increase in boron concentration, the boron adsorption by soils increased. Higher CEC, clay and organic carbon content in fine textured soils favoured higher adsorption of boron.

\section{Introduction}

It is estimated that by the year 2050, world human population will climb to 9.7 billion and India's population is projected to overtake that of China, will rise to 1.6 billion, from its current level of 1.23 billion. Skewed use of major fertilizer nutrients without micronutrients is a major concern for achieving the agricultural intensification required to feed the growing world population nutritious food. A challenge for agricultural scientists is to feed the world population with nourishing food. On the other hand, expectations for higher grain productivity in the past caused decreased content of micronutrients in grains. The issue of deficiency of micronutrients is related with food and nutritional security. Role of micronutrients in food production is well recognized and documented but their importance in nutritional security and human health is increasing in current era. Boron (B) is one of the important micronutrient required for balanced growth of plants. In India, the extent of boron deficiency was initially reported about 2\% in the year 1980 (Katyal and Vlek, 1985) which has now increased to 
18.3\% (Shukla et al., 2014). Boron deficiency has been widely found in highly calcareous soils of Bihar, Tamil Nadu, Eastern Uttar Pradesh and Saurashtra, sandy soils of Haryana and Rajasthan, hill and submountaneous soils of north Himalayan and NEH states and in red and lateritic soils of Orissa, Karnataka, Andhra Pradesh and Kokan region. In Himachal Pradesh, the extent of B deficiency has been found to be 18 to $50 \%$ across different districts.Availability of B is generally low in acid soils of high rainfall areas because of leaching of $\mathrm{B}$ and adsorption by aluminium $(\mathrm{Al})$ and iron $(\mathrm{Fe})$ oxide minerals. Correction of soil acidity by liming also retards B availability due to its adsorption on freshly precipitated $\mathrm{Al}$ and $\mathrm{Fe}$ hydroxides (Tsadilas and Kassioti, 2005). Continuous neglect of B replenishment over the years led to emergence of B deficiency across the soils and crops in India, and widespread deficiencies are now noticed in the areas that were generally considered rich in B. Recent estimates suggested B deficiency in one-third of over 40 thousand soil samples analysed (Shukla et al., 2012). Most of the research on soil B in India remained confined to the determination of hot water soluble B (Moafpouryan and Shukla, 2002; Sarkar et al., 2008), with only sporadic attempts of B fractionation (Datta et al., 2002; Chaudhary and Shukla, 2004).

Boron is unique, not only in its chemical properties, but also in its roles in biology. Since the discovery of boron as an essential plant nutrient, the importance of this element as an agricultural chemical has grown very rapidly and its availability in soil and irrigation water is an important determinant of agricultural production. Boron plays a major role in translocation of sugars, formation and maintenance of cell wall and cell membrane integrity. Boron deficiency is the most common and widespread problem which impairs plant growth and reduces yield. Normal healthy plant growth requires a continuous supply of $\mathrm{B}$, once it is taken up and used in the plant; it is not Trans located from old to new tissue. That is why, deficiency symptoms starts with the youngest growing tissues. Therefore, adequate B supply is necessary for obtaining high yields and good quality of agricultural crops. The present investigation therefore, aimed at sorption studies on boron fraction with different physico-chemical properties of cultivated soils of Himachal Pradesh.

\section{Materials and Methods}

Himachal Pradesh is predominantly a mountainous state located in North - West India. The state has highly dissected mountain ranges interspersed with deep gorges and valleys. It is also characterized with diverse climate that varies from semi tropical in lower hills, to semi arctic in the cold deserts areas of Spiti and Kinnaur. Altitude ranges from 350 meters to 6975 meters above mean sea level and is situated between $30^{\circ} 22^{\prime} 40^{\prime \prime} \mathrm{N}$ to $33^{\circ} 12^{\prime} 40^{\prime \prime} \mathrm{N}$ latitudes and $75^{\circ} 45^{\prime} 55^{\prime \prime} \mathrm{E}$ to $79^{\circ} 04^{\prime} 20^{\prime \prime}$ E longitudes. The state has different kinds of soils due to variations in climate, parent material, vegetation and topography etc. and different textured soils have different effect on boron sorption behaviour. Owing to these variations, soil samples from almost all the agro-climatic situations across the state have been used for accomplishing the present study. One hundred ten soil samples $(0-0.15 \mathrm{~m}$ depth) were collected randomly from different locations (Figure 1) across different districts of Himachal Pradesh and used in the present study. The collected soil samples were separately air dried, ground and passed through $2 \mathrm{~mm}$ size sieve for laboratory analysis. Particle size distribution was done by the standard Bouyoucos hydrometer method (Day, 1965). Soil pH was determined 
by glass electrode with calomel as standard (Jakson, 1973). Organic carbon was estimated by wet digestion method of Walkey and Black (1934). The cation exchange capacity was determined by leaching the soil with $1 \mathrm{~N}$ $\mathrm{NH}_{4} \mathrm{OAC}$ and subsequently displacing the adsorbed $\mathrm{NH}_{4}$ following the methods of Schollenberger and Simon (1945). The soils samples were extracted for available B by the method of Wear (1965). Activated charcoal was used so as to obtain colourless extract. Boron was estimated in clear filtrate colorimetrically using azomethine-H-method (Wolf, 1971).

\section{Results and Discussion}

\section{Physical characteristic}

\section{Mechanical analysis}

The data regarding soil separates from different locations have been given in table 1 . The soils varied quite appreciably with respect to different soil separates i.e. sand, silt and clay contents. Sand, silt and clay contents in the selected soils varied from 19.3-74.6, 14.6-43.6and5.8-36.2 per cent. About 88 per cent samples had more than 40 per cent sand whereas, 34 per cent samples had more than 60 per cent sand. About 60 per cent samples had silt content either equal to or lower than 25 per cent. Around 61 per cent samples recorded less than 25 per cent clay content. On the basis of relative proportion of different soil separates, the textural classes of the soils were determined. The texture varied from sandy loam to sandy clay. Forty nine per cent samples were sandy loam, 9 per cent were loam, 36 per cent samples were sandy clay loam and clay loam in texture and remaining 6 per cent were sandy clay in texture. Such variations in soil texture and separates could very well be explained due to the development of these soils under different climatic conditions, vegetation, topography and having varied parent materials.

\section{Chemical characteristics}

\section{Soil pH, organic carbon and cation exchange capacity}

The data presented in table 1 revealed that soils under study possessed wide variations in soil $\mathrm{pH}$, organic carbon (OC) and cation exchange capacity (CEC). It ranged from 5.48-7.45, 5.30- $23.5 \mathrm{~g} \mathrm{~kg}^{-1}$ and 4.60-15.4 cmol $\left(\mathrm{p}^{+}\right) \mathrm{kg}^{-1}$ with a mean value of $6.55 \pm$ $0.46,11.4 \pm 4.01 \mathrm{~g} \mathrm{~kg}^{-1}$ and $10.5 \pm 2.67 \mathrm{cmol}$ $\left(\mathrm{p}^{+}\right) \mathrm{kg}^{-1}$. Around 14 per cent soils were acidic in nature $(\mathrm{pH}<6.0), 67$ per cent samples had $\mathrm{pH}$ between 6.0 and 7.0 and 19 per cent of soil samples possessed alkaline soil reaction $(\mathrm{pH}>7.0)$. A cursory look at data revealed that 60 per cent of the soil samples were high in organic carbon and 40 per cent samples were medium. Overall 49 per cent of samples had organic carbon $<10.8 \mathrm{~g} \mathrm{~kg}^{-1}$. Similar results had been reported by Sharma et al., (1996) and Minhas et al., (1997). The wide variation in CEC across different locations was due to differences in soil texture and organic carbon content observed in the current study. Another reason for this variation might be varied $\mathrm{CaCO}_{3}$ content in the soils due to sedimentary parent material (Sharma and Kanwar, 2010). The higher CEC in the soils having higher organic matter were also reported by Mahajan et al., (2007).

\section{Boron fractions}

Data pertaining to different fractions of boron have been presented in table 2. A close look at the data embodied in table 2 revealed that readily soluble boron ranged between 0.12 and $0.55 \mathrm{mg} \mathrm{kg}^{-1}$ with an average value of $0.30 \pm 0.12 \mathrm{mg} \mathrm{kg}^{-1}$ which is 1.16 per cent of total boron. Similar results have also been reported by other researchers (Chaudhary and Shukla, 2003; Diana and Beni, 2006). The data on specifically adsorbed boron indicated that the values ranged from 0.21 to $0.62 \mathrm{mg}$ 
$\mathrm{kg}^{-1}$ with a mean of $0.42 \pm 0.12 \mathrm{mg} \mathrm{kg}$. Specifically adsorbed $\mathrm{B}$ represents that fraction of B which is specifically adsorbed onto clay surfaces or associated with organic matter in soil (Jin et al., 1987) and it is just a small component of total B. The overall relative proportion of this fraction worked out to be just 1.6 per cent of total B. This is in agreement with the findings of other workers (Wojcik, 2000; Xu et al., 2001). Oxide bound boron varied from 0.26 to $1.67 \mathrm{mg} \mathrm{kg}^{-1}$ with a mean value of $0.63 \pm 0.27 \mathrm{mg} \mathrm{kg}^{-1}$, comprised 2.4 per cent of total boron (Table 2). This fraction did not follow a regular pattern of increase or decrease from coarse textured to fine textured soils, because the amount of oxide bound fraction mainly depended upon presence or absence of iron or aluminium oxides and hydroxides as well as organic matter. There will be more adsorption of carboxylic and phenolic groupson the exchange sites present on $\mathrm{Al}$ and $\mathrm{Fe}$ oxides and their hydroxides due to greater organicmatter content, rendering lesser sites for the adsorption of B species (Kaundal et al., 2014). The organically bound boron ranged between 0.32 and $2.34 \mathrm{mg} \mathrm{kg}^{-1}$ with an average value of $1.16 \pm 0.46 \mathrm{mg} \mathrm{kg}^{-1}$ (Table 2 ). This fraction constituted 4.5 per cent of total boron. Such a high proportion of this fraction in soil may be ascribed to lowtemperature conditions in Himachal Pradesh, restricting mineralization of organic matter and release of adsorbed boron. Organic carbon content in soils has been reported as the contributor for this fraction (Hou et al., 1994; Chaudhary and Shukla, 2003). Residual $B$ was the most dominant pool of B, contributing about 90.3 per cent towards the total B. Many workers have reported greater proportion of residual $\mathrm{B}$ fraction (more than 90\%), irrespective of soil and climatic conditions (Hou et al., 1994; Xu et al., 2001; Raza et al., 2002; Chaudhary and Shukla, 2003). The amount of residual boron varied as 19.5 to $25.7 \mathrm{mg} \mathrm{kg}^{-1}$ with a mean value of $23.3 \pm 1.39 \mathrm{mg} \mathrm{kg}^{-1}$.

Fig.1 Locations of the soil samples

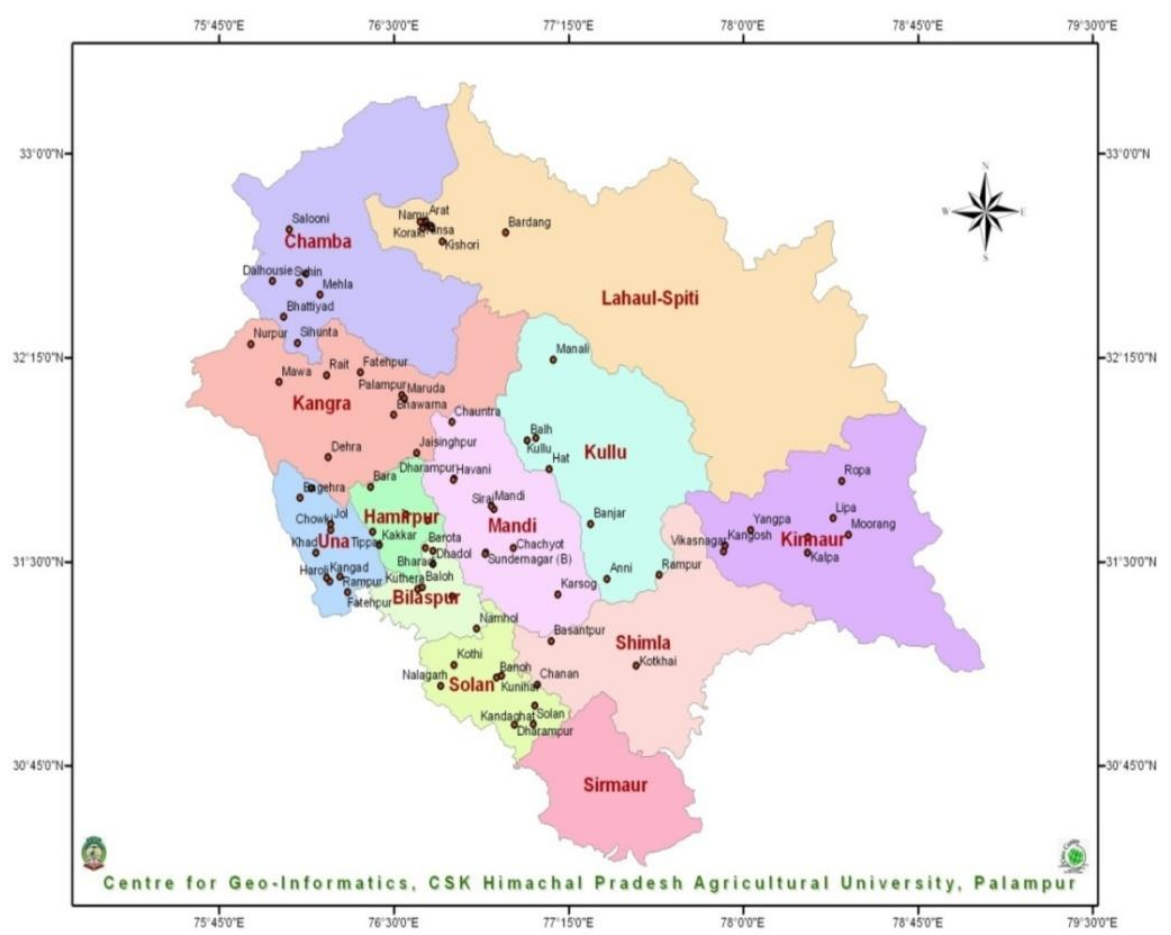


Table.1 Soil physio-chemical properties of mechanical separates (sand, silt, clay) and Soil $\mathrm{pH}$ $(1: 2.5)$, organic carbon (OC) $\left(\mathrm{g} \mathrm{kg}^{-1}\right)$ and cation exchange capacity (CEC) $\left(\mathrm{cmol}\left(\mathrm{p}^{+}\right) \mathrm{kg}^{-1}\right)$

\begin{tabular}{|c|c|c|c|c|c|c|c|c|}
\hline \multirow{2}{*}{ S.N. } & \multirow{2}{*}{\multicolumn{2}{|c|}{ Districts }} & \multicolumn{3}{|c|}{ Physical } & \multicolumn{3}{|c|}{ Chemical } \\
\hline & & & Sand & Silt & Clay & pH & OC & CEC \\
\hline \multirow[t]{3}{*}{1} & Shimla & Range & $36.6-72.2$ & $18.4-29.1$ & $6.9-33.9$ & $6.32-6.88$ & $9.6-15$ & $6.2-14.3$ \\
\hline & & Mean & 50.38 & 24.33 & 22.48 & 6.54 & 12.00 & 11.20 \\
\hline & & $\mathrm{SD}( \pm)$ & 16.96 & 4.46 & 12.63 & 0.24 & 2.28 & 3.59 \\
\hline \multirow[t]{3}{*}{2} & Hamirpur & Range & $33.0-69.9$ & $16.5-31.2$ & $6.1-34.7$ & $6.01-7.21$ & $8.1-20.1$ & 7.3-15 \\
\hline & & Mean & 50.52 & 23.12 & 24.67 & 6.84 & 13.60 & 12.23 \\
\hline & & $\mathrm{SD}( \pm)$ & 15.62 & 5.39 & 12.20 & 0.43 & 4.30 & 2.82 \\
\hline \multirow[t]{3}{*}{3} & Kangra & Range & $19.3-65.5$ & $21.5-43.6$ & $10.1-33.4$ & $5.48-6.6$ & $6.9-12.9$ & $8.4-13.7$ \\
\hline & & Mean & 47.59 & 29.77 & 20.90 & 5.98 & 9.33 & 10.71 \\
\hline & & $\mathrm{SD}( \pm)$ & 17.60 & 8.21 & 9.91 & 0.36 & 2.08 & 2.17 \\
\hline \multirow[t]{3}{*}{4} & Mandi & Range & $32.7-66.5$ & $20.5-40.4$ & $10.7-34.8$ & $5.71-7.45$ & $6.8-16.8$ & $9.3-13.1$ \\
\hline & & Mean & 48.80 & 28.76 & 20.94 & 6.49 & 12.10 & 10.89 \\
\hline & & $\mathrm{SD}( \pm)$ & 10.01 & 6.78 & 8.43 & 0.61 & 3.67 & 1.56 \\
\hline \multirow[t]{3}{*}{5} & Una & Range & $41.2-66.3$ & $17.2-30.8$ & $9.4-34.8$ & $5.89-7.14$ & $5.5-12.1$ & $4.8-12.4$ \\
\hline & & Mean & 52.81 & 23.44 & 22.03 & 6.52 & 8.72 & 9.28 \\
\hline & & $\mathrm{SD}( \pm)$ & 10.20 & 5.11 & 9.82 & 0.37 & 2.23 & 2.77 \\
\hline \multirow[t]{3}{*}{6} & Chamba & Range & $41.2-66.3$ & $17.2-30.8$ & $9.4-34.8$ & $5.82-7.1$ & $7.2-16.2$ & $7.8-15.2$ \\
\hline & & Mean & 52.81 & 23.44 & 22.03 & 6.51 & 10.90 & 11.09 \\
\hline & & $\mathrm{SD}( \pm)$ & 10.20 & 5.11 & 9.82 & 0.53 & 3.48 & 2.92 \\
\hline \multirow[t]{3}{*}{7} & Kullu & Range & $46.2-60.1$ & $17.6-32.1$ & $15.3-30.2$ & $6.34-6.98$ & $9.9-21.4$ & $9.9-14.9$ \\
\hline & & Mean & 51.43 & 23.07 & 23.53 & 6.67 & 16.05 & 11.87 \\
\hline & & $\mathrm{SD}( \pm)$ & 5.34 & 5.00 & 5.68 & 0.22 & 3.83 & 1.79 \\
\hline \multirow[t]{3}{*}{8} & Kinnaur & Range & $38.7-74.6$ & $14.6-36.1$ & $5.8-33.8$ & $6.01-7.38$ & $5.8-19.7$ & 4.6-13.9 \\
\hline & & Mean & 56.71 & 23.25 & 18.35 & 6.76 & 11.80 & 10.08 \\
\hline & & $\mathrm{SD}( \pm)$ & 15.11 & 6.58 & 9.89 & 0.51 & 4.65 & 3.39 \\
\hline \multirow[t]{3}{*}{9} & Solan & Range & $36.5-72.2$ & $18.8-34.0$ & $7.6-36.2$ & $5.86-6.82$ & $7.6-12.9$ & $7.1-13.6$ \\
\hline & & Mean & 46.79 & 28.39 & 23.41 & 6.48 & 10.49 & 10.73 \\
\hline & & $\mathrm{SD}( \pm)$ & 11.74 & 5.35 & 9.52 & 0.36 & 1.66 & 2.11 \\
\hline \multirow[t]{3}{*}{10} & Bilaspur & Range & $30.5-70.8$ & $17.2-23.5$ & $10.3-34.9$ & $6.02-7.03$ & $7.6-23.5$ & $7.5-15.4$ \\
\hline & & Mean & 54.63 & 21.73 & 21.25 & 6.59 & 13.29 & 10.53 \\
\hline & & $\mathrm{SD}( \pm)$ & 13.78 & 5.59 & 10.80 & 0.34 & 5.37 & 3.16 \\
\hline \multirow[t]{6}{*}{11} & Lahul\&Spiti & Range & $42.6-73.2$ & $18.4-34.6$ & $6.3-28.8$ & $5.98-7.07$ & $5.3-19.8$ & $6.3-28.8$ \\
\hline & & Mean & 60.61 & 23.16 & 14.24 & 6.64 & 9.57 & 8.46 \\
\hline & & $\mathrm{SD}( \pm)$ & 11.77 & 5.57 & 8.11 & 0.46 & 4.26 & 2.28 \\
\hline & Total & Range & 19.3-74.6 & $14.6-43.6$ & 5.8-36.2 & $5.48-7.45$ & 5.3-23.5 & 4.6-15.4 \\
\hline & Samples & Mean & 53.2 & 24.7 & 20.3 & 6.55 & 11.4 & 10.5 \\
\hline & & $\mathbf{S D}( \pm)$ & 13.0 & 6.13 & 9.54 & 0.46 & 4.01 & 2.67 \\
\hline
\end{tabular}


Table.2 Boron fractions $\left(\mathrm{mg} \mathrm{kg}^{-1}\right)$ of soils in mechanical separates

\begin{tabular}{|c|c|c|c|c|c|c|c|}
\hline Category & & $\begin{array}{c}\text { Readily } \\
\text { soluble B }\end{array}$ & $\begin{array}{l}\text { Specifically } \\
\text { adsorbed B }\end{array}$ & $\begin{array}{c}\text { Oxide } \\
\text { bound B }\end{array}$ & $\begin{array}{c}\text { Organically } \\
\text { bound B }\end{array}$ & & To \\
\hline $\begin{array}{c}\text { Coarse } \\
\text { (n }\end{array}$ & $\begin{array}{l}\text { Range } \\
\text { Mean } \\
\operatorname{SD}( \pm)\end{array}$ & $\begin{array}{c}0.12-0.38 \\
0.21 \\
0.08\end{array}$ & $\begin{array}{c}0.21-0.52 \\
0.33 \\
0.09\end{array}$ & $\begin{array}{c}0.27-1.36 \\
0.66 \\
0.27\end{array}$ & $\begin{array}{l}.68 \\
1 \\
0\end{array}$ & $\begin{array}{c}19.5-23.9 \\
22.3 \\
1.16\end{array}$ & $\begin{array}{c}20.6-26.7 \\
24.4 \\
1.57\end{array}$ \\
\hline $\begin{array}{c}\text { Medium } \\
\text { textured } \\
(n=36)\end{array}$ & $\begin{array}{l}\text { Mea } \\
\text { SD( }\end{array}$ & $\begin{array}{l}0.37 \\
0.09\end{array}$ & 0.08 & $\begin{array}{l}0.61 \\
0.28\end{array}$ & $\begin{array}{l}1.35 \\
0.45\end{array}$ & 0.82 & $\begin{array}{l}26.9 \\
1.30\end{array}$ \\
\hline $\begin{array}{r}\text { Fine } t \\
(n\end{array}$ & $\begin{array}{l}\text { Range } \\
\text { Mean } \\
\operatorname{SD}( \pm)\end{array}$ & $\begin{array}{c}0.49-0.55 \\
0.52 \\
0.02\end{array}$ & $\begin{array}{c}0.60-0.62 \\
0.61 \\
0.01\end{array}$ & $\begin{array}{c}0.41-0.70 \\
0.60 \\
0.13\end{array}$ & $\begin{array}{c}1.18-2.21 \\
1.78 \\
0.44\end{array}$ & $\begin{array}{c}24.9-25.3 \\
25.1 \\
0.15\end{array}$ & $\begin{array}{c}27.9-29.2 \\
28.7 \\
0.60\end{array}$ \\
\hline & $\begin{array}{l}\text { Range } \\
\text { Mean } \\
\text { SD }( \pm)\end{array}$ & $\begin{array}{c}0.12-0.55 \\
0.30 \\
0.12\end{array}$ & $\begin{array}{c}0.21-0.62 \\
0.42 \\
0.12\end{array}$ & $\begin{array}{c}0.26-1.67 \\
0.63 \\
0.27\end{array}$ & $\begin{array}{c}0.32-2.34 \\
1.16 \\
0.46\end{array}$ & $\begin{array}{c}19.5-25.7 \\
23.3 \\
1.39 \\
\end{array}$ & $\begin{array}{c}20.6-29.5 \\
25.8 \\
1.99 \\
\end{array}$ \\
\hline
\end{tabular}

Table.3 Relationship of boron fractions with mechanical separates and chemical properties

\begin{tabular}{lcccccc}
\hline \multicolumn{1}{c}{ Soil Properties } & Sand & $\begin{array}{c}\text { Physical } \\
\text { Silt }\end{array}$ & Clay & pH & OC & CEC \\
\hline Readily soluble B & $-0.74 * *$ & 0.21 & $0.88^{* *}$ & $0.43^{* *}$ & $0.71^{* *}$ & $0.95^{* *}$ \\
Specifically adsorbed B & $-0.75^{* *}$ & $0.25^{*}$ & $0.87 * *$ & $0.40^{* *}$ & $0.70^{* *}$ & $0.95^{* *}$ \\
Oxide bound B & 0.01 & $0.22^{*}$ & -0.17 & $-0.82^{* *}$ & -0.20 & -0.12 \\
Organically bound B & $-0.52^{* *}$ & 0.09 & $0.65 * *$ & $0.38^{* *}$ & $0.97 * *$ & $0.76^{* *}$ \\
Residual B & $-0.79 * *$ & $0.33^{* *}$ & $0.86 * *$ & $0.31 * *$ & $0.73^{* *}$ & $0.96^{* *}$ \\
Total B & $-0.77^{* *}$ & $0.31^{* *}$ & $0.84 * *$ & $0.25^{*}$ & $0.79 * *$ & $0.95^{* *}$ \\
\hline
\end{tabular}

Table.4 Relationship among different boron fractions

\begin{tabular}{lcccccc}
\hline & $\begin{array}{c}\text { Readily } \\
\text { soluble }\end{array}$ & $\begin{array}{c}\text { Specifically } \\
\text { adsorbed }\end{array}$ & $\begin{array}{c}\text { Oxide } \\
\text { bound }\end{array}$ & $\begin{array}{c}\text { Organically } \\
\text { bound }\end{array}$ & Residual & Total \\
\hline Readily soluble & 1.00 & & & & & \\
Specifically adsorbed & $0.98^{* *}$ & 1.00 & & & & \\
Oxide bound & $-0.29 * *$ & $-0.28^{*}$ & 1.00 & & & \\
Organically bound & $0.77^{* *}$ & $0.75^{* *}$ & -0.21 & 1.00 & & \\
Residual & $0.88^{* *}$ & $0.86^{* *}$ & -0.06 & $0.81^{* *}$ & 1.00 & 1.00 \\
Total & $0.87^{* *}$ & $0.88^{* *}$ & 0.01 & $0.86^{* *}$ & $0.99^{* *}$ & 1.00 \\
\hline
\end{tabular}


It can be inferred that this fraction constituted highest fraction of boron in comparison to other fractions in all types of soils. The residual boron showed a variation in different textured soils. All the above fractions i.e. readily soluble, specifically adsorbed, oxide bound, organically bound and residual boron were summed up to get total B content of the soil. The total boron content varied from 20.6 to $29.5 \mathrm{mg} \mathrm{kg}^{-1}$ with an average value of $25.8 \pm 1.99 \mathrm{mg} \mathrm{kg}^{-1}$. The results are in agreement with the findings Hadwani et al., (1989) who reported significant positive relationship between total and available boron fraction. Zerrari et al., (1999) reported that the adsorbed B content of the soils was $0.87 \%$ of the total B fractions.

\section{Relationship of boron fractions with mechanical separates and chemical properties}

The correlation of different boron fractions with mechanical separates (i.e. sand, silt and clay) have been presented in the table 3 and it can be seen from the table that sand content had significant and negative relationship with all the boron fractions except oxide bound $(\mathrm{r}=$ 0.01). The silt content had a significant and positive correlation with specifically adsorbed boron $\left(\mathrm{r}=0.25^{*}\right)$, oxide bound $\left(\mathrm{r}=0.22^{*}\right)$, residual boron $\left(\mathrm{r}=0.33^{* *}\right)$ and total boron $(\mathrm{r}=$ $\left.0.31^{* *}\right)$ and positive but non- significant relationship with readily soluble boron $(\mathrm{r}=$ $0.21)$ and organically bound boron $(r=0.09)$. Clay content showed significantly positive correlation with all boron fractions viz. readily soluble $\left(\mathrm{r}=0.88^{* *}\right)$, specifically adsorbed $(\mathrm{r}=$ $0.87 * *)$, organically bound $\left(\mathrm{r}=0.65^{* *}\right)$, residual $\left(\mathrm{r}=0.86^{* *}\right)$ and total boron $(\mathrm{r}=$ $0.84 * *)$, except oxide bound boron $(\mathrm{r}=-0.17)$. Anitha et al., (2013) also found positive correlation of clay with boron fractions. Correlation coefficients of boron fractions with soil properties viz. soil $\mathrm{pH}$, organic carbon and CEC were worked out and reported in table 3. Soil $\mathrm{pH}$ showed significantly positive correlation with all boron fractions except oxide bound boron $(\mathrm{r}=-0.82 * *)$. The negative relationshipprobably might bedue to decrease in sesquioxide contents present with an increase in soil pH (Dey et al., 2015). Organic carbon was highly correlated with readily soluble $(\mathrm{r}=$ $0.71 * *)$, specifically adsorbed $\left(\mathrm{r}=0.70^{* *}\right)$, organically bound $\mathrm{B}(\mathrm{r}=0.97 * *)$. These three soil B fractions mostly contributed to B availability in the soil and can be termed as labile B pools (Table 4). Significant correlation of these fractions with organic carbon indicated that soil organic matter is an important parameter contributing towards availability of B in soils (Mathur and Sudan, 2011). Organic carbon also had a significant and positive correlation with residual $\left(\mathrm{r}=0.73^{* *}\right)$ and total boron $(\mathrm{r}=0.79 * *)$. This positive relationship may be explained as that organic carbon is source of boron due to which there is not much transformation from the residual to other pools, resulting higher residual boron in the soils having higher organic matter. Oxide bound boron was negatively and non- significantly related with organic carbon $(r=-0.20)$. This may be due to adsorption of carboxylic and phenolic groups on the exchange sites on $\mathrm{Al}$ and $\mathrm{Fe}$ oxides and their hydroxides, due to greater organic-matter content, rendering fewer sites for the adsorption of $\mathrm{B}$ species. Cation exchange capacity also followed the same pattern as that of soil $\mathrm{pH}$ and OC and possessed significantly positive correlation with all the boron fractions except oxide bound boron $(r=-0.12)$. These results were in line with the findings of Kaundal et al., (2014) and Dey et al., (2015).

\section{Relationship among different boron fractions}

All the boron fractions except oxide bound boron were significantly and positively correlated with each other. Similar findings have been stated by various other researchers (Datta et al., 2002 and Sarkar et al., 2008). The greatest significant correlation was observed between residual boron and total boron $(\mathrm{r}=$ 0.99**) followed by relationship between readily soluble and specifically adsorbed boron $\left(\mathrm{r}=0.98^{* *}\right)$. The greatest correlation between residual $\mathrm{B}$ and total $\mathrm{B}$ might be due to the dominant role played by residual $\mathrm{B}$ fraction among all the extracted fractions as it 
contributed to the tune of $90.3 \%$. The negative correlation between oxide bound and other fractions can be due to reason that these fractions show positive correlation with soil $\mathrm{pH}$, $\mathrm{OC}$ and CEC while oxide bound fraction is negatively associated with these properties.

The cultivated soils of Himachal Pradesh are variable in texture, acidic in reaction and have medium to high organic matter, and CEC in the soils are generally moderate. Boron is an important micronutrient in the soil because of numerous important functions it performs in the metabolism, growth and development of crops. Residual fraction of $\mathrm{B}$ was the dominant fraction, constituting about $90.3 \%$ of total boron. The relative contribution of other fractions was in the order: organically bound $\mathrm{B}$ $>$ oxide bound $\mathrm{B}>$ specifically adsorbed $\mathrm{B}>$ readily soluble $B$.

\section{References}

Anitha, M.S., Kumar, K.S.A., Nair, K.M., Shivaprasad, C.R., Naidu, L.G.K. and Sarkar, D. 2013. Soil boron and its fractions in agro-climatic zones of Karnataka. Clay Res., 32: 25-33.

Chaudhary, D.R. and Shukla, L. 2003. Availability of soil boron fractions to mustard (Brassica juncea) in arid soils of Rajasthan (India). Agrochimica, 47: 173179.

Chaudhary, D.R. and Shukla, L.M. 2004. Boron status of arid soil of western Rajasthan in relation to their characteristic. J. Indian Soc. Soil Sci., 52: 194-196.

Datta, S.P., Rattan, R.K., Suribabu, K. and Datta, S.C. 2002. Fractionation and colorimetric determination of boron in soils. J. Plant Nutr. Soil Sci., 165: 179184.

Day, P.R. 1965. Particle fraction and particle size analysis. pp. 545-567 in: C.A. Black, (eds.) Methods of Soil Analysis. Part 1. Agronomy 9. American Society of Agronomy, Madison, WI.

Dey, A., Dwivedi, B.S., Datta, S.P., Meena, M.C. and Agarwal, B.K. 2015. Soil boron status: impact of lime and fertilizers in an Indian long-term field experiment on a Typic paleustalf. Acta Agriculturae Scandinavica, Section B - Soil Plant Sci., 65: 54-62.

Diana, G. and Beni, C. 2006. Effect of organic and mineral fertilization on soil boron fractions. Agricoltura Mediterranea, 136: 70-78.

Dwivedi, B.S., Ram, M., Singh, B.P., Das, M. and Prasad, R.N. 1990. Differential response of crops to boron fertilization in acid Alfisols. Indian J. Agric. Sci., 60: 122-127.

Hadwani, G.J., Gandhi, A.P. and Yadav, B.S. 1989. Depth wise distribution of different form of boron in relation to soil of western Gujarat. J. Indian Soc. Soil Sci., 37: 295-300.

Hou, J., Evans, L.J. and Spiers, G.A. 1994. Boron fractionation in soils. Commun. Soil Sci. Plant Anal., 25: 1841-1853.

Jackson, M.L. 1973. Soil Chemical Analysis, Prientice Hall of India Pvt. Ltd. New Delhi

Jin, J., Martens, D.C. and Zelazny, L.W. 1987. Distribution and plant availability of soil boron fractions. Soil Sci. Soc. Am. J., 51: 1228-1231.

Katyal, J.C. and Vlek, P.L.G. 1985. Micronutrient problem in tropical Asia. Fertil. Res., 7: 69-94.

Kaundal, A., Sharma, S.K., Kumar, P., Sankhyan, N. and Dutta, J. 2014. Distribution of boron forms in relation to soil characteristics, chemical fertilizers, and amendments in an acid alfisol of northwestern Himalayas. Commun. Soil Sci. Plant Anal., 45: 1772-1783.

Mahajan, A., Sharma, S.K., Gupta, R.D. and Sharma, R. 2007. Morphological, physical and chemical properties of soils from North West Himalayas. Bulgarian J. Agric. Sci., 13: 607-618.

Mathur, R. and Sudan, P. 2011. Relationship and distribution of various forms of boron with different physicochemical properties of soil in Bikaner district. J. Chem. Pharma. Res., 3: 290-294. 
Minhas, R.S., Minhas, H.K. and Verma, S.D. 1997. Soil characterization in relation to forest vegetation in the wet temperate zone of Himachal Pradesh. J. Indian Soc. Soil Sci., 45: 146-151.

Moafpouryan, G.R. and Shukla, L.M. 2002. Status of available boron in major soil series of Delhi. Ann. Agric. Res., 23: 554557.

Niaz, A., Ahmed, W., Zia, M.H. and Malhi, S.S. 2013. Relationship of soil extractable and fertilizer boron to some soil properties, crop yields and total boron in cotton and wheat plants on selected soils of Punjab, Pakistan. J. Plant Nutr., 36: 343-356.

Raza, M., Mermut, A.R., Schoenau, J.J. and Malhi, S.S. 2002. Boron fractionation in some Saskatchewan soils. Can. J. Soil Sci., 82: 173-179.

Sarkar, D., Mandal, B., Kundu, M.C. and Bhat, J.A. 2008. Soil properties influence distribution of extractable boron in soil profile. Commun. Soil Sci. Plant Anal., 39: 2319-2332.

Schollenberger, C.J. and Simon, R.H. 1945. Determination of Exchange capacity and exchangeable bases in soil - ammonium acetate method. Soil Sci., 59: $13-20$

Sharma, S.S., Totawat, K.L. and Shyampura, R.L. 1996. Characterization and classification of soils in a toposequence over Basaltic Terrain. J. Indian Soc. Soil Sci., 44: 470-475.

Sharma, V. and Kanwar, B.B. 2010. Copper status and its relation with soil properties in pea growing soils of high hills dry temperate zone of Himachal Pradesh. Indian J. Agric. Res., 44: 32-37.
Shukla, A.K., Tiwari, P.K. and Prakash, C. 2014. Micronutrients deficiencies vis-a vis food and nutritional security of India. Indian J. Fert., 10: 94-112.

Shukla, A.K., Behera, S.K., Subba Rao, A. and Singh, A.K. 2012. State-wise micro and secondary nutrients recommendation for different crops and cropping systems. Res. Bull., No. 1/2012. All India Coordinated Research Project of Micro and Secondary Nutrients and Pollutant Elements in Soils and Plants. IISS, Bhopal. pp. 1-77.

Tsadilas, C.D. and T. Kassioti. 2005. Influence of liming and nitrogen forms on boron uptake by tobacco. Commun. Soil Sci. Plant Anal., 36: 701-708.

Wear, J.I. 1965. Boron. pp 1059-1063. In: C.A.Black et al., (Eds), Methods of Soils Analysis. Part2. Agronomy 9.American Society of Agronomy, Madison, WI.

Wojcik, P. 2000. Availability of soil boron fractions to M.26 apple rootstock. J. Plant Nutr., 23: 1025-1035.

Wolf, B. 1971. The determination of boron in soil extracts, plant materials compost, manures, water and nutrient solution. Commun. Soil Sci. Plant Anal., 2: 363374.

Xu, J.M., Wang, K., Bell, R.W., Yang, Y.A. and Huang, L.B. 2001. Soil boron fractions and their relationship to soil properties. Soil Sci. Soc. Am. J., 65: 133138.

Zerrari, N., Moustaoui, D. and Verloo, M. 1999. The forms of boron in soil, effect of soil characteristics and availability for the plants. Agrochimica, 43: 77-88.

\section{How to cite this article:}

Kusum Kumari, Gazala Nazir, Ajeet Singh and Pardeep Kumar. 2017. Studies on Boron Fractions with Different Physico-Chemical Properties of Cultivated Soils of Himachal Pradesh. Int.J.Curr.Microbiol.App.Sci. 6(6): 1547-1555. doi: https://doi.org/10.20546/ijcmas.2017.606.182 